\title{
Study of Early Adhesion of Some Oral Microflora Representatives to Basic Materials of Removable Dentures
}

\author{
Sviatoslav Rozhko*, Roman Kutsyk
}

\begin{abstract}
An increase in the number of removable denture constructions being produced leads to an increase in the number of complications, which, in turn, reduces the timing of the effective use of orthopedic structures. At present, the problem of treating prosthetic stomatitis and their prevention has not been resolved. Considering the current socio-economic situation, orthopedic treatment of the patients with removable dentures will be relevant for some more time.

Microbiological studies of the ability of basic materials to adhere different types of microorganisms onto their surfaces were performed. There were used 7 different types of resins manufactured according to different technologies.

Having performed a series of microbiological studies on the adhesive ability of basic materials, the following results were obtained. The control was glass, the average index of adhesion to which was $0.69 \pm 0.02$. The greatest adhesive ability to various types of microorganisms was found in acrylic resins based on polymethyl methacrylate, namely auto-polymer resin Protacryl and resin Sinma. Accordingly, the smallest adhesive properties were seen in non-monomer resins, such as Polian, Nylon, Biocryl with adhesion indices of $0.75 \pm 0.04,0.72 \pm 0.03,0.78 \pm 0.03$, respectively.
\end{abstract}

Keywords

basic resins; microorganisms; adhesion; oral cavity

Ivano-Frankivsk National Medical University, Ivano-Frankivsk, Ukraine

*Corresponding author: rozhkosviatoslav@gmail.com

Copyright (C)Sviatoslav Rozhko, Roman Kutsyk, 2019

\section{Problem statement and analysis of the latest research}

Adhesion to the tissues of the oral cavity (mucous membranes, crowns of the teeth), as well as to basic materials of orthopedic and orthodontic structures, allows bacteria to withstand clearance (which is provided by swallowing movements and a permanent washing action of saliva), leads to the colonization of various parts of the oral cavity. The composition of the oral microflora varies with age, under the influence of damage to teeth and their loss [1, 2], against the background of concomitant somatic pathology in the presence of partial or complete dentures $[3,6,8]$.

The formation of microbial plaque on the surface of denture bases is a common problem in orthopedic dentistry, which requires increased attention to the oral cavity hygiene and the care of the dentures themselves. Microbial colonization of the basal surface in the area of the prosthetic bed serves as a trigger factor in the development of prosthetic stomatitis. Dental plaque on the bases of dentures is predominantly bacterial and may differ significantly in species composition $[4,9]$. The resident microor- 


\section{Study of Early Adhesion of Some Oral Microflora Representatives to Basic Materials of \\ Removable Dentures - 2/7}

ganisms of the prosthetic bed are $\alpha$-hemolytic streptococci ( $S$. oralis, $S$. mitis), representatives of the $S$. mutans-group, and actinomycetes Actinomyces viscosus. In the experiments in vitro, it was demonstrated that $S$. oralis and $A$. viscosus easily colonize the materials of the bases of acrylic resin dentures. Microbial colonization (along with mechanical injuries) is an important factor in reducing the timing of the use of removable dentures. After extensive exposure (for 6 weeks) to the culture A. viscosus using scanning electron microscopy, on the surfaces of acrylic resin Palapress (Kulzer, Wehrheim, Germany) and Triad VLC (Dentsply, DeTrey, Dreieich, Germany), there were observed lesions that visually resembled the shells. Similar damage and increased surface roughness were detected after the exposure to a polyacid-modified restorative composite material Dyract (Dentsply/DeTrey, Konstanz, Germany) with $S$. mutans and A. naeslundii cultures. Such changes in superficial characteristics of materials enhance the process of formation of dental plaque.

Among researchers, considerable attention is attracted to the study of adhesion of yeast fungi Candida albicans to the polymeric materials in connection with the seriousness of the problem of candidiasis prosthetic stomatitis [7, 10, 11].

Therefore, the objective of the research was to compare the adhesive ability of resident and transient representatives of the oral microflora to various basic materials used for manufacturing removable dentures.

\section{Materials and Methods}

To evaluate the adhesive ability of microorganisms, there were used 7 types of samples of basic materials using in the clinic of orthopedic dentistry to make bases of full and partial removable dentures.

Table 1 represents physical and chemical compositions and methods of their polymerization.

Ready resins' models for the experiment looked like plates of $2 \mathrm{~mm}$ thick and $1 \mathrm{~cm}^{2}$ square. As control, glass plates of similar size were used. The experimental and control models were placed in a sealed cellophane package and then were sterilized by X-ray irradiation at a dose of $0.44 \mathrm{mGy}$ for

\subsection{0 seconds.}

The study used strains of opportunistic microorganisms that represent the facultative-anaerobic transient microflora of the oral cavity $[1,2,3]$, as well as $\alpha$-hemolytic streptococci Streptococcus oralis, $S$. gordonii, $S$. sanguis as the main representatives of the resident microflora of this biotope. Microbial cultures were isolated from the mucous membrane of the oral cavity (prosthetic bed, gingival pockets) in the patients with prosthetic stomatitis wearing removable denture, and identified on the basis of morphological, cultural properties and biochemical tests using the following kits: STAPHYtest 16, STREPTOtest 16, ENTEROtest 24 (Lachema, Czech Republic).

Adhesive ability of microorganisms was evaluated according to the method developed by V.N. Tsariov [5]. Suspensions were made in a physiological saline solution at a concentration of $1 \times 10^{6} \mathrm{CFU} / \mathrm{m}$, based on the optical turbidity standard from the daily cultures of bacteria grown on blood agar, and from 48-hour C. albicans cultures grown on a Sabouraud's medium. The investigated sample of the material was cultured in bacteriological test tubes in a microbial suspension during 1 hour at a temperature of $37^{\circ} \mathrm{C}$. After this, the sample was transferred into a new sterile test tube and was washed three times in a sterile physiological solution to remove microbial cells that were not adhesive. For the separation of the adhesive bacteria from the resins surface, the washed samples were placed for 5 minutes into sterile ultrasound wash basin for prosthetics TSM $226289(50 \mathrm{~W}, 42 \mathrm{KHz})$ with ultraviolet irradiator turned off. The laundering of the adhesive microorganisms was performed in $1.0 \mathrm{ml}$ of sterile nutrient broth, after which the number of viable microbial cells was determined by serial dilutions. Cultivation of staphylococci and streptococci was performed on blood agar, collibacillus - on the medium of Endo, fungi of the genus Candida - in the Sabouraud's medium.

Having performed the bacterial inoculation, the number of isolated colonies grown from microbial cells, which were adhesive to the sample of the material, was counted. Then, there was performed the re-calculation at $1 \mathrm{~cm}^{2}$ of the sample and the values 
Table 1. Characteristics of the materials used in the study.

\begin{tabular}{lccc}
\hline Brand name & Chemical composition & Manufacturer & $\begin{array}{c}\text { Method of } \\
\text { polymerization }\end{array}$ \\
\hline Polian IC & Polymethyl methacrylate & Bredent, Germany & Heat polymerization \\
\hline Breflex (Bre.Flex) & Polyamide/nylon & Bredent, Germany & Heat polymerization \\
\hline Nylon & Polyamide & & Heat polymerization \\
\hline Protacryl-M & $\begin{array}{c}\text { Fluorine-containing } \\
\text { acrylic copolymer, } \\
\text { methylmethacrylate }\end{array}$ & $\begin{array}{c}\text { Joint-stock partnership } \\
\text { "Stoma", Ukraine }\end{array}$ & Cold polymerization \\
\hline Vinacryl & Polymethyl methacrylate & & Heat polymerization \\
\hline Biocryl & $\begin{array}{c}\text { Polymethyl methacrylate } \\
\text { SINMA }\end{array}$ & $\begin{array}{c}\text { SHEU-DENTAL, } \\
\text { Germany }\end{array}$ & $\begin{array}{c}\text { Stampingeat } \\
\text { polymerization }\end{array}$ \\
\hline & $\begin{array}{c}\text { Fcrylic copolymer, a } \\
\text { mixture of acrylic } \\
\text { monomers and } \\
\text { oligomers. }\end{array}$ & $\begin{array}{c}\text { Joint-stock partnership } \\
\text { "Stoma", Ukraine }\end{array}$ & Heat polymerization \\
& & & \\
\hline
\end{tabular}

of the decimal logarithm for the number of viable microbial cells were determined. For each of the test cultures, the percentage of adhesive microorganisms was determined, and the adhesion index was calculated using the formula:

$$
I A=\operatorname{IgA} / \operatorname{Ig} N
$$

where IA - index of adhesion; A - the number of adhesive microbes; $\mathrm{N}$ - number of microbes in the initial suspension.

Experiments on testing the adhesion of each test culture to each sample of the material were repeated three times. The results were processed by the method of variation statistics.

\section{Results and Discussion}

The experimental microbiological studies performed demonstrated that the studied samples of materials differed significantly in their ability to absorb and retain microbial cells from the suspension (Table 2).

The adhesion of microorganisms to the control material (glass) was very weak. After a 60-minute exposure to the glass surface, which was used as a control, only $1-5 \%$ of the microbial cells, presented in the suspension, were attached. Only strains of Streptococcus gordonii (14.04\%), Staphylococcus aureus (11.80\%) and Candida albicans (20.71\%) were distinguished by a relatively high adhesive ability to glass. Thus, the average index of adhesion of microorganisms to glass was $0.69 \pm 0.02$ (Table 3).

The study of adhesion of resident representatives of the oral microflora, namely $\alpha$-hemolytic streptococci to various polymer materials is surely of the greatest practical interest (Fig. 1).

The strains $S$. oralis and $S$. sanguis showed the least adhesive ability to studied basic materials. $S$. oralis was the least adhesive to the basic nonpolymeric materials (Polian, Breflex and Biocryl) being 0.34 . The greatest ability was demonstrated by auto-polymer resin Protacryl with the index of adhesion of 0.86 and resin for non-removable structures Sinma with an adhesion index of 0.82 . A slightly different tendency was demonstrated by basic materials in relation to $S$. sanguis: the smallest index was in relation to Polian - 0.34, while the largest index was in relation to auto-polymer resin Protacryl - 0.86 . 
Table 2. Comparative analysis of adhesive ability of basic resins (according to the average adhesion index) in relation to different groups of tested microorganisms.

\begin{tabular}{lcccccccc}
\hline Microorganisms & Polian & Breflex & Nylon & Protacryl & Vinacryl & Biocryl & SINMA & Glass \\
\hline $\begin{array}{l}\text { Oral } \alpha \text {-hemolytic strep- } \\
\text { tococci }\end{array}$ & $0.52 \pm 0.19^{*}$ & $0.71 \pm 0.17$ & $0.73 \pm 0.14$ & $0.87 \pm 0.08^{*}$ & $0.83 \pm 0.04^{*}$ & $0.70 \pm 0.17$ & $0.83 \pm 0.12^{*}$ & $0.75 \pm 0.08$ \\
\hline $\begin{array}{l}\text { Oral } \beta \text {-hemolytic strep- } \\
\text { tococci }\end{array}$ & $0.94 \pm 0.04^{*}$ & $0.90 \pm 0.01^{*}$ & $0.81 \pm 0.01^{*}$ & $0.86 \pm 0.16^{*}$ & $0.91 \pm 0.11^{*}$ & $0.83 \pm 0.09^{*}$ & $0.91 \pm 0.01^{*}$ & $0.66 \pm 0.16$ \\
\hline Oral staphylococci & $0.87 \pm 0.06^{*}$ & $0.90 \pm 0.03^{*}$ & $0.73 \pm 0.01$ & $0.85 \pm 0.09$ & $0.88 \pm 0.01^{*}$ & $0.84 \pm 0.06$ & $0.84 \pm 0.08$ & $0.72 \pm 0.12$ \\
\hline $\begin{array}{l}\text { Fungi of the genus Can- } \\
\text { dida }\end{array}$ & $0.91 \pm 0.01$ & $0.81 \pm 0.06^{*}$ & $0.53 \pm 0.04$ & $0.74 \pm 0.06$ & $0.87 \pm 0.01^{*}$ & $0.73 \pm 0.03$ & $0.65 \pm 0.01$ & $0.69 \pm 0.22$ \\
\hline $\begin{array}{l}\text { Microorganisms that are } \\
\text { not ecologically related } \\
\text { to the oral cavity }\end{array}$ & $0.72 \pm 0.10$ & $0.82 \pm 0.02^{*}$ & $0.71 \pm 0.10$ & $0.82 \pm 0.07^{*}$ & $0.79 \pm 0.07^{*}$ & $0.78 \pm 0.07^{*}$ & $0.69 \pm 0.12$ & $0.61 \pm 0.07$ \\
\hline $\begin{array}{l}\text { For all tested microor- } \\
\text { ganisms }\end{array}$ & $0.75 \pm 0.04^{*}$ & $0.81 \pm 0.03^{*}$ & $0.72 \pm 0.03$ & $0.84 \pm 0.02^{*}$ & $0.84 \pm 0.02^{*}$ & $0.78 \pm 0.03^{*}$ & $0.79 \pm 0.03^{*}$ & $0.69 \pm 0.02$ \\
\hline
\end{tabular}

Table 3. Index of adhesion of microorganisms to different types of basic resins.

\begin{tabular}{|c|c|c|c|c|c|c|c|c|c|}
\hline \multirow[t]{2}{*}{ Microorganisms } & \multirow{2}{*}{$\begin{array}{l}\text { Microbial loading of the } \\
\text { initial suspension, CFU/ml }\end{array}$} & \multicolumn{8}{|c|}{ Index of adhesion } \\
\hline & & Polian & Breflex & Nylon & Protacryl & Vinacryl & Biocryl & SINMA & Glass \\
\hline S. aureus ATCC 25923 & 4.75 & $0.91 *$ & $0.92 *$ & 0.72 & $0.92 *$ & $0.88^{*}$ & $0.89 *$ & $0.90 *$ & 0.80 \\
\hline S. aureus MRSA & 4.61 & 0.74 & 0.79 & $0.91 *$ & $0.90 *$ & 0.69 & $0.84 *$ & $0.85^{*}$ & 0.63 \\
\hline S. epidermidis & 4.79 & $0.83 *$ & $0.87^{*}$ & 0.74 & 0.79 & $0.87 *$ & 0.80 & 0.78 & 0.63 \\
\hline E. coli & 4.63 & 0.71 & $0.79 *$ & 0.66 & $0.84 *$ & 0.71 & $0.86^{*}$ & $0.91 *$ & 0.58 \\
\hline C. albicans & 4.34 & 0.90 & 0.77 & $0.55^{*}$ & 0.79 & 0.87 & 0.74 & 0.66 & 0.84 \\
\hline C. tropicalis & 4.33 & $0.91 *$ & $0.85^{*}$ & 0.50 & 0.70 & $0.87 *$ & 0.71 & 0.65 & 0.53 \\
\hline$\beta$-hemol. Str. group $B$ & 4.77 & $0.52 *$ & 0.82 & 0.77 & 0.83 & 0.86 & 0.70 & $0.36^{*}$ & 0.71 \\
\hline$\beta$-hemol. Str. group $A$ & 6.22 & $0.91 *$ & $0.89^{*}$ & $0.82 *$ & $0.85^{*}$ & $0.99 *$ & 0.78 & $0.92 *$ & 0.54 \\
\hline$\beta$-hemol. Str. group $G$ & 5.51 & $0.98 *$ & $0.90^{*}$ & 0.80 & 0.87 & 0.84 & $0.89 *$ & $0.91 *$ & 0.78 \\
\hline$\alpha$-hemol. Str. gordonii & 5.57 & 0.93 & $0.98^{*}$ & $0.97 *$ & $0.98 *$ & $0.89 *$ & 0.95 & $0.99 *$ & 0.85 \\
\hline$\alpha$-hemol. Str. oralis & 6.05 & $0.28 *$ & 0.80 & $0.52 *$ & 0.78 & 0.79 & 0.81 & 0.69 & 0.75 \\
\hline$\alpha$-hemol. Str. sanguis & 4.98 & $0.34 *$ & $0.34^{*}$ & 0.70 & $0.86^{*}$ & 0.82 & $0.34 *$ & 0.82 & 0.65 \\
\hline
\end{tabular}


Candida fungi are known to play a leading role in the occurrence of prosthetic stomatitis (Fig. 2). Adhesive ability of the fungi of genus Candida to glass was $0.69 \pm 0.22$ being a control benchmark. The basic material Nylon and resin for non-removable orthopedic structures Sinma were characterized by the least adhesive ability. We can explain this result by the possible presence of a residual monomer, especially in the resins of Sinma and Protacryl. It should be noted that non-monomeric basic resins were found to be intermediate according to their ability to adhesion.

The results of studying $E$. coli adhesion to basic materials were indicative. The adhesion index to the control samples was 0.58 . The most adhesive ability was demonstrated by basic resins with the presence of the residual monomer, namely Protacryl and Sinma. Accordingly, the least adhesive ability was demonstrated by modern non-monomeric resins Polian, Breflex, Nylon, Vinacryl.

The study of the adhesive ability of basic resins by the average adhesion index showed a different adhesive ability of the above-mentioned materials. It is especially necessary to note the adhesive properties of $\alpha$-hemolytic Str. gordonii, which were the highest in comparison with all other types of microorganisms that were studied.

After studying the adhesive ability of different types of microorganisms to basic materials and their comparison, we have reached the following scientific assumptions. As a control sample, we have used glass with an average adhesion index of $0.69 \pm 0.02$. The acrylic resins based on polymethyl methacrylate, namely auto-polymer resin Protacryl and Sinma had the highest adhesive ability to all microorganisms. Accordingly, non-monomeric resins such as Polian, Nylon, Biocryl had the smallest adhesive properties. The results obtained will be the basis for further experimental studies on the influence of basic materials on the oral microflora.

\section{Conclusions}

The experimental microbiological studies performed demonstrated that acrylic resins of the polymethyl methacrylic group have high adhesive properties in relation to various microorganisms of the oral cavity, while non-monomeric basic resins have the least adhesive properties.

\section{Prospects of Further Researches}

Further study of the influence of various basic materials on the oral microflora, especially its ability to biofilm formation on the surface of resins, is promising.

\section{References}

[1] Divnych TYa, Rozhko MM, Kutsyk RV. Zmina mikroflory rotovoii porozhnyny $\mathrm{v}$ zalezhnosti vid terminu korystuvannia znimnymy konstruktsiiamy zubnykh proteziv. Galician Medical Journal. 2007;14(2):26-29.

[2] Kalivradzhiyan ES, Podoprigora AV. Vliyaniye nesyemnogo protezirovaniye na mikrofloru polosti rta. Proceedings of the XVIth AllRussian Scientific Practical Conference. Moscow. 2006;274-277.

[3] Mykhailenko TM, Kutsyk RV. Mikrobne chyslo ta defitsyt mikrobnoho chysla yak intehralni pokaznyky stanu mikrobiotsenozu slyzovoii obolonky proteznoho lozha ta bazysiv proteziv u osib $\mathrm{z}$ riznym rivnem hihiieny znimnykh konstruktsii. Archive of Clinical Medicine. 2010;2(16):38-42.

[4] Nidzelskyi MYa, Krynychko LR. Rezultaty vyprobuvan bazysnykh akrylovykh plastmas shchodo yikh skhylnosti do zaselennia umovnopatohennymy mikroorhanizmamy. Ukraiinskyi stomatolohichnyi almanakh. 2010;5:27-28.

[5] Tsarev VN. Adgezisnaya aktivnost bakterialnoy i gribkovoy flory polosti rta k novym bazisnym plastmassam na osnove neylona (Eksperimentalnyye issledovaniya). Ros stomatol zhurnal. 2005;2:7-10.

[6] Bal BT, Yavuzyilmaz H, Yücel M. A pilot study to evaluate the adhesion of 

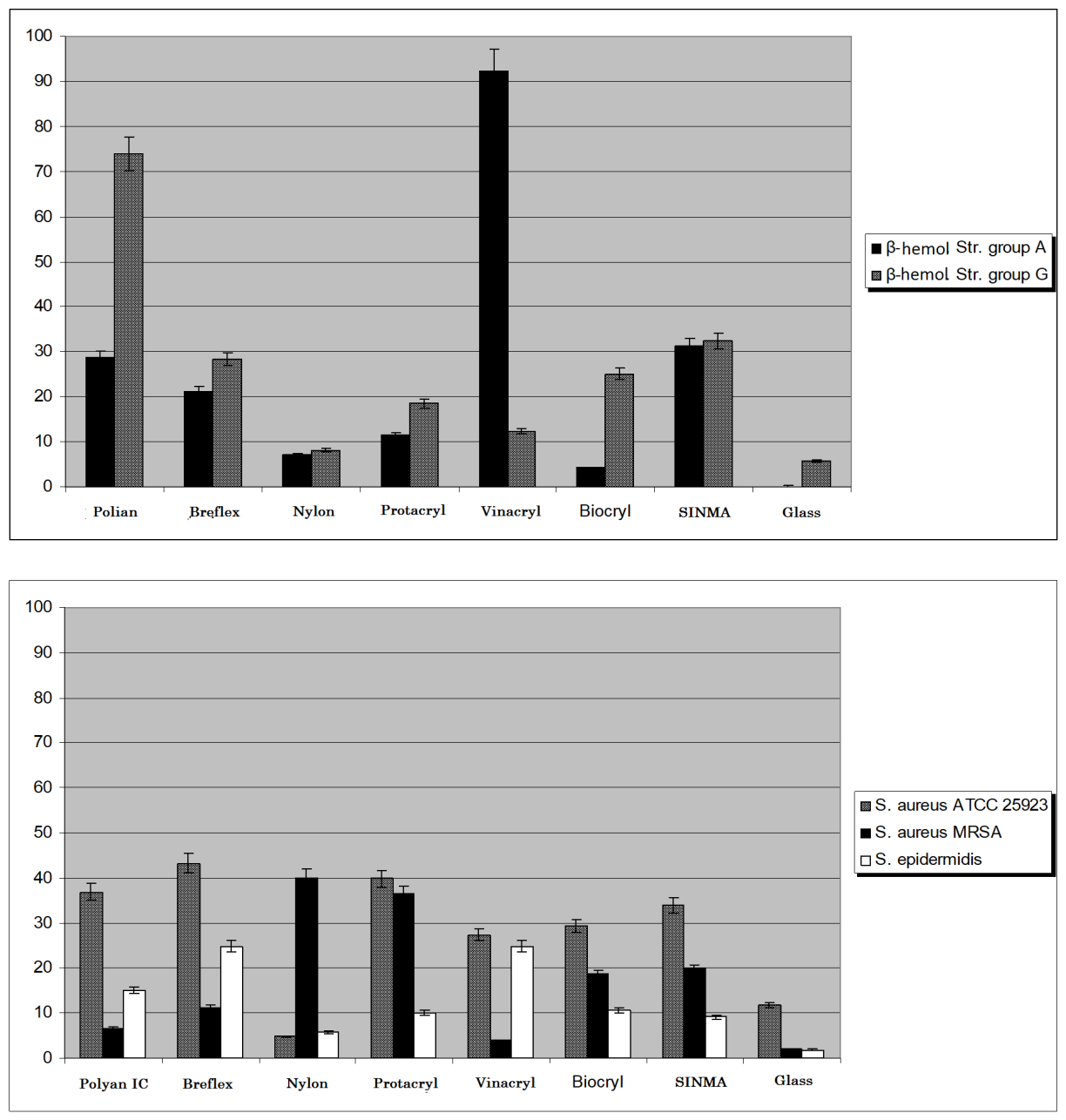

Figure 1. Percentage of oral streptococci and staphylococci adhesive to the materials of basic resins.

oral microorganisms to temporary soft lining materials. J Oral Sci. 2008;50(1):18. DOI: https://doi.org/10.2334/ josnusd.50.1 [PMid:18403876]

[7] Kagermeier-Callaway AS, Willershausen $\mathrm{B}$, Frank $\mathrm{T}$ et al. In vitro colonisation of acrylic resin denture base materials by Streptococcus oralis and Actinomyces viscosus. Int Dent J. 2000; 50(2):79-85. DOI: https://doi.org/10.1002/ j.1875-595x.2000.tb00803.x [PMid:10945186]

[8] Nikawa H, Hamada T, Yamamoto T. Denture plaque - past and present concerns. J Dent. 1998;26(4):299-304.
DOI: https://doi.org/10.1016/ S0300-5712(97)00026-2

[9] Okita N, Orstavik D, Orstavik J et al. In vivo and in vitro studies on soft denture materials: Microbial adhesion and tests for antibacterial activity. Dent Mater. 1991;7(30):155160. DOI: https://doi .org/10.1016/ 0109-5641(91) 90035-W

[10] Samaranayake LP, McCourtie J, MacFarlane TW. Factors affecting the in vitro adherence of Candida albicans to acrylic surfaces. Arch Oral Biol. 1980;25(8-9):611615. DOI: https://doi.org/10.1016/ 0003-9969(80) 90076-X 

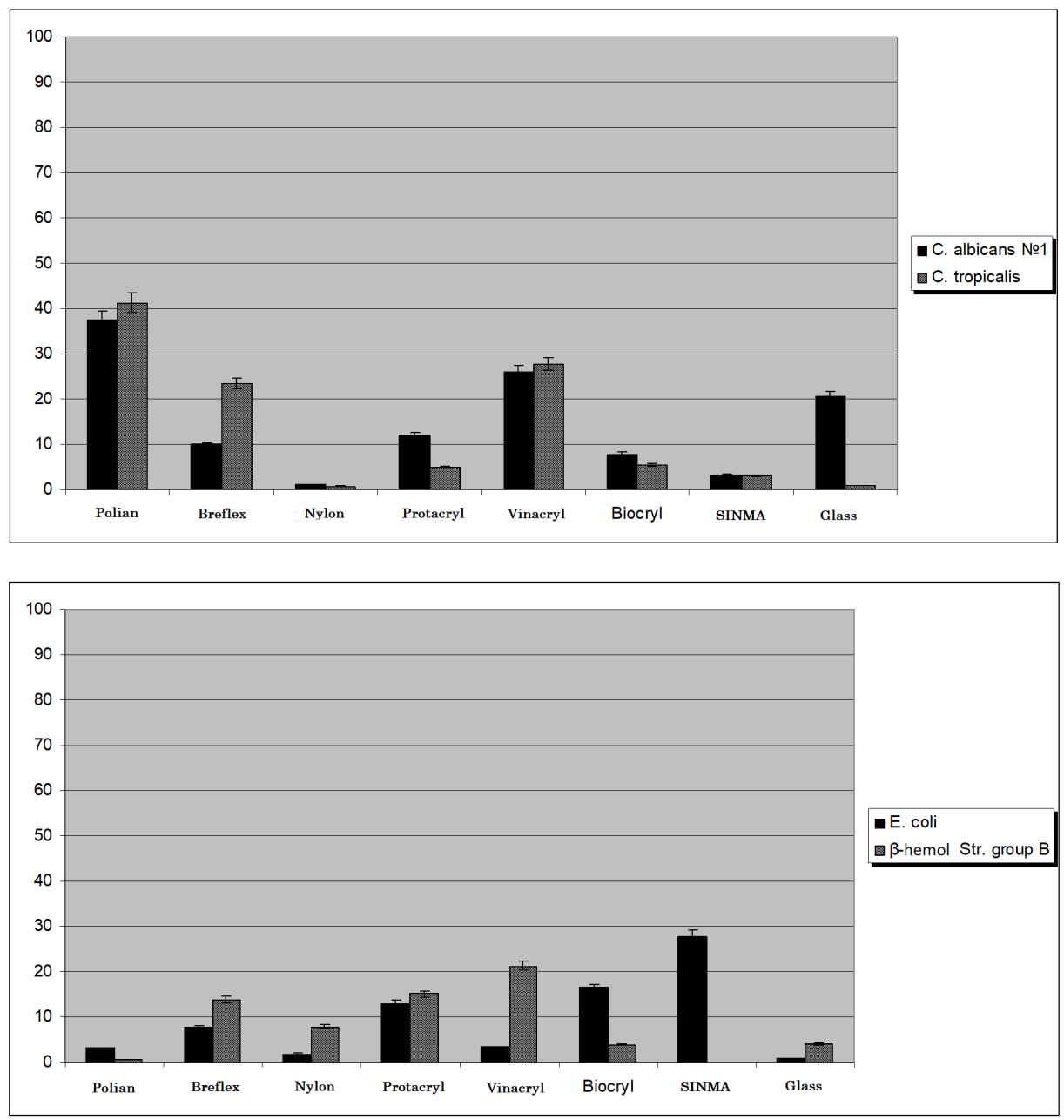

Figure 2. Percentage of oral streptococci and staphylococci adhesive to the materials of basic resins.

[11] Vieira APC, Senna PM, da Silva WJ et al. Long-term efficacy of denture cleansers in preventing Candida spp. biofilm recolonization on liner surface. Braz Oral Res. 2010;24(3):342343. DOI: https://doi.org/10. $1590 /$ S1806-83242010000300014

[PMid:20877973]

Received: 2019-06-27

Revised: $2019-09-08$

Accepted: $2019-09-18$ 